\title{
The Lures of Neo-Victorianism Presentism (with a Feminist Case Study of Penny Dreadful)
}

\begin{abstract}
Commonly credited with a distinctly presentist agenda, neo-Victorian works invite readers/viewers to infer seeming parallels and continuities between the nineteenth century and postmodernity. The discernment of presentism's exact operations, however, presupposes an informed audience with a comparatively high level of historical knowledge and sophistication, which cannot be assumed by works targeting a diverse mass market, as in the case of televisual productions. This often results in mixed messages that undermine neoVictorianism's ethical agenda and endorsement of liberal politics, pitting critical selfconscious engagement with the past against its naïve and unreflective consumption. This essay considers presentism's complex ramifications via an overview of the presentist debate and its application to neo-Victorian studies, followed by a case study of Season Three of Showtime/Sky's popular Penny Dreadful (2014-2016) series, created by John Logan, specifically the plotline centred on the characters Brona Croft, Dr Victor Frankenstein, and Dorian Gray. Their triangulated narrative, I argue, reveals a disturbing tension between the series' apparent avowal of feminist ideals and activism, on the one hand, and a parodic skewing of both, on the other, raising issues of potential viewer manipulation and insidious historical distortion.
\end{abstract}

Keywords: 'antithetical critical presentism', feminism, historical distortion, misogyny, neoVictorianism, paedophilia, Penny Dreadful, presentism, sexuality, Take Back the Night. 
Historical fiction and film in general, and neo-Victorian works in particular, ${ }^{1}$ are inherently presentist: they are grounded in the contemporary contexts of their production and recreate the past with historical hindsight that is part of the present's purview. As Steven Connor points out, "[i]t has often been remarked that novels dealing with historical events and themes cannot avoid conscious or unconscious reflection on the relation between the narrated past and the present that narrates it" (Connor 1996: 140). The same holds true for other media, such as television: they can only 're-present' the earlier period from present-day perspectives but not represent it in the sense of bearing first-hand witness to it, even when pretending otherwise (for instance, through the use of first-person 'Victorian' narrators). Most neoVictorian fictions, however, foreground their presentism overtly, ${ }^{1}$ due to what Ann Heilmann and Mark Llewellyn term their "high degree of self-analytical drive" (Heilmann and Llewellyn 2010: 5) or, in Connor's terms, intensely conscious or self-conscious reflection. Critics commonly use this criterion to differentiate the neo-Victorian mode from unreflective historical fiction and costume drama that employ nineteenth-century settings for mere window dressing: the latter tend to ignore the dialogic nature of rewriting the period. They lack overt self-awareness of "the metahistoric and metacultural ramifications" of their own "historical engagement" (Heilmann and Llewellyn 2010: 7), disregarding the "various ways in which the present is negotiated" (3) alongside the recreated past. Genuinely neo-Victorian works, then, seem obliged to acknowledge both their recycled nineteenth-century and contemporary contexts and to duly reflect on the present in tandem with - rather than at the expense of - the past, lest they be accused of disingenuousness or even historical distortion.

After outlining neo-Victorian critics' equivocal stance on presentism with reference to Showtime/Sky's Penny Dreadful (2014-2016), created and written by John Logan, this article considers the wider controversy surrounding presentism in literary and cultural studies and that debate's relevance to neo-Victorian studies. It then moves to a more detailed case study of Penny Dreadful's Season Three (2016) to examine the series' presentist skewing of feminist histories for its popular mass market. Specifically, I focus on the plotline centred on the tubercular prostitute Brona Croft (Billie Piper), murdered and resurrected as 'Lily' by Dr Victor Frankenstein (Harry Treadaway), and her lover Dorian Gray (Reeve Carney). Read as an anachronistic parody of the twentieth- and twenty-first-century Take Back the Night campaign, this narrative strand reveals a disturbing misogynist subtext at odds with Penny Dreadful's apparent endorsement of feminist ideals and activism. Undermining its own and neo-Victorianism's commitment to liberal politics, Penny Dreadful raises important questions about current trends in presentism, suggesting we may need to radically rethink and complicate our notions of neo-Victorian self-consciousness in the light of different kinds of consumption.

\section{Neo-Victorianism and Presentism: Preliminary Reflections}

Theorists regularly foreground presentism as a defining feature of the neo-Victorian project and its exploration of the dialectical relationship of past and present between the shifting poles of nostalgia and rejection, historical influence and resistance, continuities and difference, cultural legacies and change. As early as 2001, Christian Gutleben stressed the revisionist impact of twentieth-century political correctness on the period's fictional reconstructions, producing retributive denouncements of "the injustice towards some of its ill-used or forgotten representatives such as women, the lower classes or homosexuals" (Gutleben 2001: 10). It is almost as though the Victorians' own representations of their nineteenth-century world and its material traces cannot be relied upon to tell it 'as it really was' and must be imaginatively supplemented with modern-day insight and greater frankness 
to produce a 'realer' disclosure of the period, warts and all - what Phillip Barrish (albeit in different context) calls "the realest real thing" (Barrish 2001: 3), "the really real" (4) and "realer-than-thou' one-upmanship" (4). ${ }^{1}$ This implicitly positions neo-Victorian artists and audiences as freer from ideological blind spots and hence superior (because more clearsighted or less benighted) cultural critics of the nineteenth century than the Victorians themselves.

Two forms of neo-Victorian writing in particular - postcolonial fictions and biofictions (which re-imagine real-life individuals) - incline towards pronounced selfconscious presentism. The strand of postcolonial novels set in nineteenth-century Australia and Tasmania, focusing on race relations, thus intervenes overtly in the so-called 'History Wars': ongoing cultural debates about the legacies of colonialism's violation of the continent, its island territories, and its Aboriginal peoples, discriminatory (Anglocentric) forms of present-day Australian national identity, and the indigenous population's eventual rights to compensation and restitution of ancestral lands. ${ }^{1}$ Presentism thus contributes to fictional/filmic modes of contemporary witness-bearing to historical trauma and injustice, providing symbolic commemoration and restitution to history's victims and an important source of audience 'edutainment'. ${ }^{1}$ The same ethical tendencies can be discerned in neoVictorian works chronicling discrimination against other subalterns, including women. Indeed Penny Dreadful seems to fall into this latter category on account of its prominent female protagonists, Vanessa Ives (Eva Green) and Brona/Lily, who are both socially vilified and victimized as fallen women and monstrous madwomen on account of their gender and sexuality. Yet postcolonial fiction and biofiction also resort to dubious appropriation, sensationalism and historical misrepresentation for the sake of political agendas, such as exposing imperialist atrocities or recovering elided 'Other' histories of queer subjects or freak show performers (see Ho Lai-Ming 2012; Kohlke 2013; Davies 2015). Richard Flanagan's Wanting (2008), for example, depicts Sir John Franklin as a paedophile rapist of his Aboriginal foster-daughter Mathinna to condemn British imperialism's metaphorical 'rape' of Tasmania - in the absence of any historical evidence to support this scenario.

Gutleben appositely points out the risks of opportunistically tailoring the past to deliver "precisely what the general public wants to read" or view (Gutleben 2001: 11), playing to popular concerns, such as racism or sexism, and to market trends. This tendency is especially apparent in neo-Victorianism's graphic treatments of sex, which is rendered "complementary" rather than "antithetical" to the purportedly repressive historical setting, with "Victorianism and sexuality partaking of the same allegiance to current fashion" (Gutleben 2001: 176). Our own hypersexualised consumerist age is superimposed upon the re-imagined Victorian era, potentially obfuscating actual history. The filmmakers' choice of Billie Piper to play Brona/Lily thus seems no coincidence, with many viewers likely to recall the actress as the twenty-first-century, high-class, London call girl Hanna Baxter aka 'Belle de Jour' in the successful ITV series Secret Diary of a Call Girl (2007-2011). Piper's identification with this prior role strategically adds to Penny Dreadful's mass market sex appeal, as does the series' use of full nudity and extended sex scenes.

Also focussing on the nineteenth century's present-day commodification, Kate Mitchell argues that neo-Victorian fictions "grapple with the issue of how to package the Victorian past for the tastes and demands of contemporary readers" and with "what it means to fashion the past for consumption in the present": whether to resort to "superficial detail" simply to create a general 'retro' feel or to engage with the past's "complexities as a unique historical moment that is produced in a particular relationship to the present" (Mitchell 2010a: 3). When Penny Dreadful introduces the trope of paedophilia, for instance, the sensationalist effect is in keeping with the cheap, nineteenth-century, mass produced fiction for the newly literate, urban lower classes from which the series borrows its name. 
Simultaneously, however, the trope alludes to our own "historical moment" in which widespread child sex abuse, facilitated by the internet and social media, has assumed frightening proportions. The historical "detail" of Victorian paedophilia is placed "in a particular relationship to the present", positioned as harbinger and uncanny Doppelgänger of the same reprehensible phenomenon in our own time.

Accordingly, the selective figuration of the past - what we choose to memorialise on page and screen but, even more crucially, how we do so - offers telling disclosures of how we understand ourselves and our own culture and time. Nadine Boehm-Schnitker and Susanne Gruss aptly stress the nineteenth century's serviceability to both postmodern memory and identity politics: "the neo-Victorian project looks into the desires and contexts that tinge and shape the perspectives of our contemporary construction of memory; moreover, it explores the changing purposes with which we fashion the past-and with it, ourselves" (Boehm-Schnitker and Gruss 2014: 1). The approach of the centenary of the Representation of the People Act 1918, which first granted British women the (albeit only partial) right to vote, ${ }^{1}$ as well as various commemorative events, television programmes and artistic works dedicated to the women's suffrage movement, ${ }^{1}$ furnish some of the present-day "contexts" and "perspectives" that have moved the history of first-wave feminism back into the cultural limelight. The exact shapes of "our contemporary construction" of this past struggle impacts on current debates about postfeminism and on public perceptions of the extent to which progress towards full gender equality has or has not been achieved - not least as regards freedom of sexual expression, derogatory stereotypes of women as whores, and the risks of sexploitation, themes also explored in Penny Dreadful. Arguably, in spite of its nineteenthcentury Gothic setting and supernatural elements, the series' engagement with 'real' feminist issues thus participates in the renegotiation or "self-fashioning" (Boehm-Schnitker and Gruss 2014: 1) of current gender identity politics and "who we are today" (5).

Yet different modes of representing history can evoke very different audience responses. While a socio-realist or documentary-style approach will tend to elicit empathy or pathos, a light-hearted comic mode might not only invite sympathetic laughter but also disparaging dismissal - for instance, of feminist history as something not worth taking seriously. Meanwhile melodramatic or Gothic modes, which dominate Penny Dreadful, can solicit horror at historical injustices, but also voyeuristic fascination or even sadistic enjoyment in (women's) depicted suffering. Readers and viewers will be far less likely to notice such manipulation, however, if they fail to register when and how historical and contemporary contexts are deliberately altered or 'misused' to provoke a particular response. Louisa Hadley thus warns of the critical necessity "to be aware of both contemporary and Victorian contexts" when dealing with neo-Victorian texts; otherwise our "contemporary uses of the Victorians" can effect a distorting make-over, which sometimes "results in the erasure of the historical specificity of the Victorians" and their actual period context (Hadley 2010: 6, added emphasis). Indeed, the specificity of our own postmodernity may be similarly obliterated.

\section{The Presentist Debate: An Overview}

Presentism as both a concept and methodology has already provoked a significant degree of controversy, though so far focused mainly on early modern and Shakespeare studies. As Barrish remarks, '[u]sed pejoratively, 'presentist' refers to criticism perceived as blithely and unselfconsciously projecting a critic's [or reader's] own political or social concerns onto the literature of an earlier period" (Barrish 2005: 19) - or more generally, onto the culture of a bygone era, which becomes a quasi prior super-text subjected to reinterpretation. This definition can be extended to the creative process whereby artists insinuate current attitudes 
and sociocultural contexts into the historical worlds they recreate for present-day consumption. Hence presentism may produce unintentional misreadings of the past in so far as individuals remain unaware of (or in self-denial about) the extent to which their modern mind-sets infiltrate, inform and possibly distort their assessments of another age and its cultural products, discourses, and ideologies.

Presentism's detractors argue that instead of engaging with historical events and textual evidence on their own terms - what they meant to historical subjects living then presentists privilege readings that validate their own contemporary beliefs. Feminist convictions, for instance, might lead to interpretations of Shakespeare's The Taming of the Shrew as distinctly misogynistic, though it might not have been deemed so in the playwright's own time. Similarly, Miriam E. Burstein, blogging as 'The Little Professor', formulates ironic 'Rules for Writing Neo-Victorian Novels' to mock presentist readings and rewritings of nineteenth-century gender roles: "All middle- and upper-class Victorian wives are Sexually Frustrated, Emotionally Unfulfilled, and possibly Physically Abused", while "Any outwardly respectable man will a) have frequent recourse to Prostitutes, b) have a Dark Secret, and/or c) be Jack the Ripper" (Burstein 2006: n.p.). Uncannily prescient of Penny Dreadful's depictions of gender relations, these rules highlight presentism's tendency towards facileness, flattening out the complexities of Victorian culture to match audiences' stereotypical expectations of the period.

Presentism thus accentuates what Norman Holland deems narrative's circular tendency whereby "identity recreates itself", because as readers we selectively "use the literary [or filmic] work to symbolize and finally to replicate ourselves" (Holland 1975, qtd. in Alcorn and Bracher 1985: 342). Reduced to our solipsistic mirror-image, the past is interpreted as always 'anticipating' modern-day subjectivities and concerns: the text becomes primarily about ourselves and our own ways of seeing the world rather than its ostensible objects of analysis. Hence presentism's detractors, Steven Seidman explains, do not regard it as "a genuinely historical approach" at all, but one that resorts to "ideological reconstructions or myths" (Seidman 1985: 14). John Holbo similarly describes presentism as "a species of error", arguing that "[t]he term denotes historicist untruth and injustice" and functions as an all too convenient apologia for applying present-day theoretical approaches (such as psychoanalytical, feminist or queer readings) anachronistically to texts (or cultures) that predate those same theories (Holbo 2008: 1097). Re-imagining the friendship between the writers Constance Fenimore and Henry James, Elizabeth Maguire's neo-Victorian biofiction The Open Door (2008), for instance, includes a gay sex scene between James and a young Italian man. Although it remains disputed whether James ever acted on his supposed closeted homosexuality, Maguire emulates James' presentist critics and biographers in offering queer re-readings of the writers' works and private life as presumed 'fact'.

Presentists discern analogies and convergences between the past and their own world and time, which risk the reductive conflation of historically distinct, complex cultures into trans-historical sameness. In Shakespeare studies, the greater temporal gap between Renaissance/Tudor and postmodern societies accentuates the difficulty of interpreting antecedent cultural products solely within the historical and material contexts of their original conception, production, and reception. Presentism's supposed "universalizing" tendencies and attendant risks of "den[ying] historical difference" (Grady 2007: n.p.) become more pronounced when analogising such widely disparate and ideologically separated cultures. We would hardly describe ourselves as 'post-Shakespeareans' or 'neo-Shakespeareans' today.

In contrast, the nineteenth century dealt with in neo-Victorian texts already looks distinctly modern. The period's own language more closely approaches present-day English usage and idiom; significant genres, media and modes (such as the novel and serialisation) came fully into their own or (as in the case of photography and cinema) first emerged during 
this era; and many features of Victorian society (including policies on child protection, new and quicker technologies of communication, the tabloid press and mass media, and the promotion of globalised free trade) persist in evolved forms today. As Christine L. Krueger remarks, "[n]o matter how vociferously we protest our postmodern condition, we are in many respects post-Victorians, with a complex relationship to the ethics, politics, psychology, and art of our [...] Victorian precursors" (Krueger 2002: xi). This makes the drawing of analogies between the nineteenth-century past and postmodern present seem much more defensible. Neo-Victorianism's typical self-reflexivity would also appear to resist any blithely naïve projections onto the past. Thus when Penny Dreadful adapts several iconic period works, such as Mary Shelley's Frankenstein (1818), Oscar Wilde's The Picture of Dorian Gray (1890), and Bram Stoker's Dracula (1897), it does so with ironic self-awareness, borrowing some of these texts' main protagonists but blatantly changing their storylines (for instance, by having Frankenstein create a viable female monster) and flagrantly introducing latter-day theoretical contexts (such as twentieth-century feminist reconceptualizations of female madness as the effects of patriarchal oppression). There is nothing accidental or unknowing about this approach, so that any resulting misreadings appear intentional rather than otherwise. Presentism thus seems less problematic in the case of neo-Victorian studies.

Neo-Victorianism transforms presentism from an inadvertent error or analytical blind spot into a purposeful, consciously pursued, critical and creative practice. This aligns neoVictorianism with the defence put forward by the advocates of presentism in Shakespeare studies, in works such as Hugh Grady and Terence Hawkes' edited collection Presentist Shakespeares (2007). Presentism is unavoidable, the argument goes, since we are all products of our particular place and time, with historically conditioned cognitive and epistemological frameworks that interpose themselves between earlier periods or period texts and their elicited meanings. In this sense, the present is much more than "an intervening, distracting fog" to be "rigorously [...] blow[n] away" by "effective literary criticism" and careful contextual reading (Grady and Hawkes 2007: 2). Rather, to borrow a now antiquated concept popular with the Victorians, the present becomes the 'aether' that mediates, disseminates and perpetuates the bygone culture's and its texts' significance.

Employed self-consciously, presentism resists the reduction of earlier cultural products to 'dead' artefacts, historical curios, or mere material commodities traded in the marketplace. It facilitates richer, more complex readings, discovering latent meanings that have hitherto been overlooked, and prevents a fall into moral relativism, whereby ethical judgement is suspended because it is deemed inappropriate to judge past actions and attitudes by present-day standards. Instead, advocates of presentism see our contemporary principles, critical theories and analytical methodologies as new tools with which to better interpret, understand, and assess the past, its achievements as well as its failings (for instance, in the misogynistic treatment or derogatory cultural representations of women). In contrast, strict historicist contextualization is "inadequate because it omits meaningful dimensions of the discourse of the text" (Seidman 1985: 14), closing down rather than opening up new avenues for deep reading, as well as refusing to acknowledge the reality-frames and background assumptions that we inevitably bring to bear on all the texts we read. Presentist practice thus allows for a more self-critical, ethically and politically engaged form of literary and cultural studies. Accordingly, Hugh Grady defines presentism as "the understanding that all our knowledge of the past, including that of [...] historical context, is shaped by the ideologies and discourses of our cultural present. Far from being an impediment to our knowledge, this understanding is its enabling foundation" (Grady 2007: n.p., added emphasis).

The notion of presentism as an 'enabler' invites comparison with Linda Hutcheon's concept of 'historiographic metafiction', based on "the paradox of the reality of the past but its textualized accessibility to us today" (Hutcheon 1988: 114, original emphasis). Since 
history is a selective narrative construct formulated with hindsight, which is itself subject to change, past reality can only be accessed through intermediating textual traces, raising crucial questions of "how do we know the past? What do (what can) we know of it now?" (Hutcheon 1988: 115). Like Hutcheon, both Shakespearean and neo-Victorian presentist critics hold that there is no such thing as a definitive concrete past in its 'natural' (that is, pre-textual, premediated) state awaiting critico-historicist discovery. This renders historicists' professed faithfulness in recouping the past 'as it really was' dubious, since their 'discovered' versions prove just as contingent as presentist constructions. Presentism is positioned as the more honest approach, because it "accept[s] the radical 'alterity' and unique 'unrecoverability' of the past" as both "mise-en-scène" and "mentalite", combatting what Peter Barry ironically calls the "delusion that if only we are relentless enough in the archival grind, we will one day recover the past and again walk the streets of Shakespeare's [or Dickens'] London" (Barry 2008: 192). Proponents of presentism point out the fallacy underlying any attempt at 'pure' or 'absolute' historicism, regarding "such a scholarly venture to be a fantasy" (Gajowski 2010: $675)$.

Presentism's defenders criticise historicists' exclusive focus on prior texts' moments of production and initial reception, which dismisses later theoretical and reception contexts as irrelevant to signification. The "insist[ence] on looking backward rather than looking forward, or looking around us" results in "one end of the temporal spectrum [...] being privileged at the expense of the other end, and all points in between" (Gajowski 2010: 680). What and how text means now is just as important, since texts accrete additional layers of meaning over time through varying reception and reproduction contexts. The figure of Dracula in Penny Dreadful, for instance, is very much a humanised monster, a tragic lover capable of true devotion in spite of his evil propensities, representing a version of vampirism that owes more to previous televisual and cinematic re-visions and their positive reception Bram Stoker's Dracula (1992), Angel (1999-2004), The Twilight Saga (2008-2010), and Dracula Untold (2014) - than to the titular horror of Stoker's Dracula. Although such presentist reinterpretations 'unmoor' the source text from its historical contexts, that same unhitching and recirculation in different post-Victorian contexts is crucial to the novel's cultural longevity and popular appeal, as well as on-going critical interest in it.

In neo-Victorian studies, then, the debate surrounding presentism shifts somewhat, not least because, unlike Shakespeare's plays, neo-Victorian works are contemporaneous with rather than antecedent to their readers and critics, products of the same cultural consciousness and extradiegetic world. Since presentism is accepted as an essential element of the neo-Victorian project, the focus falls less on its legitimacy and more on the kind of presentism employed, namely unknowing or self-conscious. Barrish pertinently differentiates "blithe or uncritical presentism" from what he terms "critical presentism": the latter "seeks new ways of reading specific literature of the past" - or, more generally, reading the nineteenth-century past - "not only in but with the social present-and of doing so selfconsciously and also productively" (Barrish 2005: 19, original emphasis). Barrish's more nuanced definition is particularly useful, because he advocates a close focus both on how presentist readings introduce deliberate changes into the past and on how they may incorporate the past in undigested form. Penny Dreadful's surreptitious manipulations of viewer response stem from just this combination of overtly acknowledged and deliberately obscured or undigested historical contexts, past and present. Hence I want to complicate Barrish's definition still further, by proposing that some forms of critical presentism - in spite of their evident self-consciousness - may not actually produce (or even intend) the more ethical effects attributed to presentism, or else unwittingly or wilfully subvert those ethical effects in the process of production. These additional forms of short-circuiting or self- 
subverting presentist practice may be termed 'antithetical critical presentism', or even, in aggravated cases, 'invidious critical presentism'.

The risks of antithetical critical presentism are heightened in the case of neo-Victorian works produced for the mass market. Neo-Victorian 'literary' or otherwise 'artistic' works can assume an informed audience, possessing a comparatively high degree of historical knowledge and readerly/critical sophistication with which to discern texts' presentist operations. Trying to appeal to a much wider and more diverse audience, televisual productions such as Penny Dreadful can make no such assumptions regarding their viewers' cultural competence, though they may still try and appeal to informed spectators also. This can result in distinctly mixed messages. Rather than facilitate self-analytical engagement with the recreated past, products of popular culture primarily aim to maximise entertainment value and hence consumption - even at the cost of scuppering their own liberal politics.

\section{Penny Dreadful: Case Study in Compromised Feminist Histories}

The introduction of full-blown postmodern feminists into nineteenth-century settings is among the most prevalent of neo-Victorian presentist tropes. Such women perform their femininity with a Butlerean self-consciousness (at times bordering on parody) of the period's full range of gender codes, roles, and stereotypes, from the dutiful daughter, selfless mother and 'Angel in the House' to the fallen woman, madwoman, female monster, and femme fatale - sometimes all in one-and-the-same character. Many female protagonists embrace a liberated, strategically deployed and sometimes hedonistic sexuality as a means of selfactualisation and empowerment, as in the case of Nancy Astley in Sarah Waters' Tipping the Velvet (1998), Sugar in Michel Faber's The Crimson Petal and the White (2002), Irene Adler in Guy Ritchie's Sherlock Holmes (2009), ${ }^{1}$ or Vanessa and Brona/Lily in Penny Dreadful. As Tara MacDonald and Joyce Goggin point out, "what is striking about the exceptional woman is that, in many ways, she figures as a kind of time-travelling figure, an anachronistic modern woman thrown back into the nineteenth century, with hyper-awareness of gender codes and even of feminist theory" (MacDonald and Goggin 2013: 7). Yet to read "the exceptional woman" as a Victorian prototype or advance guard of present-day feminism misses the extent to which she is constructed to trump real-life female trailblazers. Hence these texts often elide the historical fact that many actual Victorian feminists utilized rather different weapons in the fight for equality, such as advocacy of strict moral purity, temperance (not just as regards alcohol), and public duty (as opposed to the satisfaction of personal desires).

In neo-Victorian works, feminists' commitment to the greater good is often compromised or perverted, made to serve as a convenient excuse for the indulgence of baser drives, as in the case of Penny Dreadful's Brona, an Irish prostitute with a heart of gold who finds love with Ethan Chandler (Josh Hartnett) while already dying of consumption. At the end of Season One, Brona's death throes are hastened by suffocation at the hands of Victor Frankenstein, who resurrects her in Season Two, supposedly as a mate for his 'creature' Caliban/John Clare (Rory Kinnear) but in truth as his own sexually available Galatea or 'Lily'. Victor's scientific project functions as a presentist parody of Victorian philanthropic rescue work with fallen women which - albeit problematic from today's viewpoint in terms of its paternalistic class bias and sometimes punitive moralistic evangelism - was generally conducted in good faith and for the perceived physical and spiritual benefit of the women 'saved' from the streets. Aptly for a Gothic series focused on the exposure of secrets, but clearly presentist in its hermeneutical suspicion of Victorian values, Penny Dreadful calls into question the genuineness of the Victorians' moral agendas, which are revealed as distinctly self-serving. 
In Lily's case, however, the fallen woman refuses to be redeemed, instead falling further still, re-inventing herself as a murderous New Woman activist and, moreover, corrupting others to emulate her. As she gradually regains her memories, Lily rejects Victor's possessive love for the decadent hedonistic passions of Dorian Gray, who assists her in refashioning London's exploited streetwalkers into an army of man-hating furies wreaking destruction on the metropolis' unsuspecting male population. The unstated presentist oversimplifications are as follows: 1) all Victorian prostitutes were abused victims of patriarchy; and 2) as per Burstein's earlier cited rule, all Victorian men used/abused prostitutes. Hence all men are equally guilty and deserving of punishment.

Not coincidentally, Lily's and Dorian's first convert is the child prostitute Justine (Jessica Barden), the intended victim of a 'snuff' show saved in the nick of time by her 'good' monster rescuers. Although her age at the time of her deliverance remains unspecified, Justine reveals that, like her namesake, the Marquis de Sade's heroine, she was forcibly corrupted at age twelve, and her characterisation - her childish features and voice and her appearance in virginal white with a pink sash when she wakes in Dorian's mansion the morning after her ordeal - explicitly figure her as an under-age victim of the sex trade. Repeatedly, Dorian also addresses her as "Child" rather than by name (Logan 2016: Penny Dreadful, 3.7 and 3.8). When Justine is re-confronted with her one-time violator, now stripped naked and bound, she recounts how "[h]e bought me when I was twelve. [...] He used me as his pet whore for a time, like a monkey on a chain. When I got older, he grew tired of me and whored me out, set me up on a platform and let them fuck me ten at a time" and eventually charged his upper-class customers ten pounds a head to see her "tortured and murdered", as Dorian reminds her (Logan 2016: Penny Dreadful 3.3, original emphasis). The scene's denouement is pre-programmed: presented with a knife, Justine slits her abuser's throat and stabs him over and over again, completing her initiation into the "monumental revenge" which Lily earlier promised her (Logan 2016: Penny Dreadful 3.2).

The paedophilic plot device may be read as a presentist nod to historical and more recent UK sex crimes and child sex abuse scandals, including the Fred and Rosemary West, Rotherham, and Jimmy Savile cases, and also to the inaugural episode of Ripper Street (2012-present), 'I Need Light' (2012), which similarly culminates in the last-minute rescue of a prostitute coerced to perform in an early snuff movie. In part, Lily's orchestrated mass vengeance thus serves up a fantasy retribution against present-day perpetrators, especially those who escaped justice, as well as Victorian abusers. Yet although Penny Dreadful opens in $1891,{ }^{1}$ no mention is made of W.T. Stead's sensationalist piece of investigative journalism, 'The Maiden Tribute of Modern Babylon' (1885), which exposed widespread child prostitution in Britain's capital, or of the subsequent public scandal that led to an increase in the female age of consent from thirteen to sixteen in the Criminal Law Amendment Act of the same year. Nor is any reference made to other real-life campaigners working to publically highlight and ameliorate the plight of nineteenth-century sex workers, of whose suffering Penny Dreadful's fin-de-siècle London seems utterly oblivious. This conveys a distinctly skewed impression of the 1890s historical scene and the complex phenomenon of Victorian prostitution, which was often a temporary resort for women in economic distress and could sometimes prove a lucrative career, even leading to an upwardly mobile marriage. It also wholly disregards the non-violent, early feminist engagement on behalf of prostitutes, including the campaign led by Josephine Butler against the Contagious Diseases Acts, which were finally repealed in 1886. In the context of the plot, this seems more than an incidental oversight: it constitutes a calculated forgetting and writing out of the past.

Admittedly, the Gothic, to which the series belongs, poses particular problems for historical factuality due to the genre's frequent resort to unreality, while the lurid 'penny blood' publications, from which Penny Dreadful draws its name, promised sensationalism, 
not realism. Hence it might seem misguided to expect the latter from Logan's series. Yet as Benjamin Poore remarks, the series draws on actual "cultural history (for example, spiritualism; the Whitechapel murders; imperial adventurers)" (Poore 2016: 66), deliberately positioning itself "between period-specificity and anachronism" (77). Penny Dreadful makes a self-conscious effort to get (some) historical details right - for instance, in aspects of dress and fashion; medical treatments for hysteria; London locations such as Kew Gardens, the British Museum (since 1992 the Natural History Museum), and slums neighbourhoods; and popular pastimes and entertainments such as taxidermy, Wild West shows, wax works and séances. For the most part, Penny Dreadful thus seems intent on situating the action within a recognisable 'real' nineteenth century (albeit with an added supernatural dimension) rather than an alternative history altogether as, for instance, in some neo-Victorian steampunk fiction, such as Gail Carriger's The Parasol Protectorate (2009-2012) series. Consequently, it is legitimate to speculate why Logan chose to occlude/exclude other period details, such as the child prostitution debates, even as he insinuates these same historical discourses in undigested form into his storyline. The resulting distortion is only discernible to viewers with sufficient prior knowledge of the Victorian age. For the less informed among the audience, only familiar with previously mediated 'Dickensian' and Gothic stereotypes of the period, Penny Dreadful risks producing a 'pseudo-realistic' past, a hyperreal simulacrum, the recreated sociohistorical contexts of which are readily (mis)taken for fact. This is akin to the deliberate use of historical inaccuracies for dramatic effect in films such as Schindler's List (1993), the set of which included a never-existent road paved with fake desecrated Jewish gravestones running through the re-created Nazi labour camp at Palszów, near Krakow.

Penny Dreadful's antithetical presentism is highlighted by the equivocal disturbing coding of Lily, her female co-conspirators and their crusade. These repeatedly contradict the series' discursive feminist message and apparent advocacy for women's rights as spelled out by Lily to the street walkers assembled in Dorian's drawing room: "We are not women who crawl. We are not women who kneel. And for this, we will be branded radicals, revolutionists. Women who are strong and refuse to be degraded and choose to protect themselves are called monsters. That is the world's crime, not ours" (Logan 2016: Penny Dreadful 3.6). Rather than deconstructing these pejorative stereotypes, the series disingenuously sets out to 'brand' the women as just such monsters through what I take to be a parodic re-enactment of present-day feminist activism, specifically the Take Back the Night campaign (1970s-present) to combat sexual violence and abuse.

Lily and her militant prostitutes likewise protest against the lack of "women's safety when walking down public streets" (Take Back the Night N.d.: n.p., original italics) and the ever-present risk of male violence, but theirs is a grotesquely bloody rather than non-violent crusade that seeks to outdo the violence it contests. The ongoing Take Back the Night campaign has produced sometimes fraught alliances between (anti-porn) feminist activists and sex workers, whereas Lily dismisses the possibility of any co-operation with other women's groups; for instance, although acknowledging that "our enemies are the same", she explains to Justine that suffragettes "seek equality" while she and her private army fight for "mastery" (Logan 2016: Penny Dreadful 3.3). Even the early debates about allowing male supporters (and/or male victims of sexual violence) to participate in the campaigns are alluded to in Dorian's contested involvement. ${ }^{1}$ More significantly, various Take Back the Night events, such as the 1973 march in San Francisco, USA, and the 2006 march in Ipswich, UK, were held in response to the serial killings of prostitutes. Bizarrely, however, Penny Dreadful represses any genuine reflection on the misogynist implications of the 1888 Jack the Ripper crimes which, as did the earlier Contagious Diseases Acts, made it more dangerous than usual for women to walk the city streets without fear of attack or, in the case of nonprostitutes living near army encampments and in port cities, without fear of being wrongly 
taken for sex workers and, prior to 1886 , forced to submit to invasive medical examinations and face imprisonment in lock hospitals. Apparently unconcerned about the possible perils of London's night-time streets, even when alone and unchaperoned, Vanessa, for instance, is never accosted by men but only supernatural monsters. Yet both the Ripper panic and the controversy surrounding the Contagious Diseases Acts would still have been relatively fresh in Londoners' minds in 1891 when Penny Dreadful opens.

Additionally, the virulent sexism involved in killing fallen women is repeatedly mitigated by their deaths' filmic recontextualization. Frankenstein's murder of Brona becomes a mercy killing in the interests of science, Dorian's poisoning of his transgender lover Angelique an act of self-protection (when she discovers the secret of his immortality), and his later killing of Justine another mercy killing and assisted suicide ('saving' her from being forced to return to a life on the streets). Meanwhile Ethan's murder of Vanessa is presented as an act of love and salvation. Indeed the male anti-heroes' crimes against women pale into insignificance in contrast to the indiscriminate violence perpetrated by Lily and her devotees against men, symbolised by the grotesque pile of cut-off hands adorning the elegant dinner table in 'Ebb Tide'. While the men kill women rationally and/or reluctantly, the women revel orgastically in their male victims' violations, leading Dorian to ironically enquire of Lily, "Is it all mankind you despise or just men?" (Logan 2016: Penny Dreadful 3.7). The latter, of course, is a stock assumption about 'man-hating' feminists.

Crucially, Logan's antithetical critical presentism misrepresents the present as much as the past. Feminist solidarity and collective action are depicted as monstrous rather than promoting the public good and a more liberal, equal, and safer society ${ }^{1}$ - a fitting twentyfirst-century misogynistic tribute to (and replay of) the nineteenth-century backlash against the New Woman. As already indicated, Lily refuses to ally herself with wider public causes, such as the universal suffrage movement. Nor does she seek to fight extreme economic inequality and poverty, which drive many women into prostitution in the first place; instead, the anti-heroine happily lives a life of obscene luxury in Dorian's opulent mansion. Hence Lily's earlier cited 'feminist' manifesto comes across as filmic sophistry: in spite of the women's legitimate rage and the series' Gothic celebration of and visual indulgence in their bloody acts, the women are denigrated as feral monsters. Dorian describes Lily and himself as having "unleashed the inmates [...]. All the bedlamites come home to roost", and claims that as general of her "army of depraved whores", Lily increasingly resembles "a lion-tamer at the circus" (Logan 2016: Penny Dreadful 3.7). For all of Penny Dreadful's apparent privileging of female viewpoints (via major women protagonists, supporting characters and villains) and endorsement of female empowerment (via free sexual expression, supernatural natures or abilities, and the usurpation of traditionally male physical violence), the series' superficial feminist messages are repeatedly undercut by misogynistic subtexts. Feminism then and now is reduced to a misguided, misandrist and megalomaniacal Gothic revenge fantasy. The series' monstrous New Women signal a contemporaneity where postfeminism once more permits the indiscriminate pathologization of women under the guise of supposedly innocent, tongue-in-cheek 'fun'. And of course it all is fun - and sexy too - to watch. Yet self-conscious viewers may find their enjoyment abated by the show's slippery sexual/textual politics.

Once the occluded fin-de-siècle and current cultural contexts are taken into account, the lures of Penny Dreadful's presentism take on a different aspect. After Justine's murder of her first despoiler, she is shown engaging in a blood-soaked threesome with Lily and Dorian, which could be said to repeat rather than end her sexual exploitation. Additionally, if as implied, she is still under-age, the love-making scene constitutes a highly unethical filmic representation of 'enjoyable' paedophilia, 'legitimated' by Justine's apparent active desire. A reading against the grain, suggests that Justine, like her Sadian namesake, is being subjected 
to 'grooming' by her rescuers, with the indulgence in inappropriate sex acts presented in bad faith under the guise of the free (and freely engaged in) reciprocal pursuit of pleasure and Justine's introduction/seduction into militant feminist activism. Yet as Justine henceforth receives no remuneration for the sex act except in kind - via fine food and clothes, luxurious lodgings, 'love', and the opportunity to pursue her murderous inclinations - she becomes just as vulnerable as formerly, with Dorian stressing, "I can toss you out like the baggage you are whenever it pleases me" (Logan 2016: Penny Dreadful 3.7). Not least, of course, the liberated/liberating space of Dorian's mansion earlier provided the setting for his own sexual exploitation of Brona prior to her death and his use and murder of Angelique, presaging his final murderous violation of Justine, who 'chooses' death at his hands rather than be cast back onto the streets. Their interchange in 'No Beast So Fierce' is thus uncannily revealing; as Justine volunteers to practice knifing a punter on Dorian, he warns her that "I shan't go easy on you", to which she replies: "Then you'll play the part of a john well. I suppose you've had a lot of practice? How many women have you paid to debase? Treat me as you did them. Fuck me, you filth" (Logan 2016: Penny Dreadful 3.6). Indeed, Dorian is simultaneously the rescuer and violator, liberator and sexual exploiter, avenging angel and the Ripper's double. What, we may well ask, is the 'real' political or feminist message encoded in the series' endorsement of the seductive monster (male as well as female), bar the innocuous 'sex sells' and 'violent, murderous or perverse sex sells even better'? Penny Dreadful's neo-Victorian presentism, to borrow MacDonald and Goggin's terms, seems more "self-serving, self-satisfying, and/or self-eroticising" than intent on wielding any of the "political potential" (MacDonald and Goggin 2013: 5) it initially promises.

\section{Coda: Invidious Critical Presentism}

In the run-up to the series finale, Penny Dreadful increasingly seems to employ the Victorian period setting to indulge in presentist misogyny under cover of representing the historical patriarchal abuse and victimisation of women. 'Ebb Tide' in particular brings these tendencies to the fore, when Dorian, grown bored with the women's crusade, betrays Lily and connives in her kidnapping by Victor and the doctor's former school-friend Henry Jekyll (Shazad Latif). Demoted from conquering general to hapless madwoman, Lilly is taken to Bedlam to be injected with a serum that in Jekyll/Hyde-like fashion will split off her monstrous self, restoring the docile 'Angel of the House' to perfect obeisance. As the gloating trio of men looms above the helpless woman chained for her "own protection", Victor promises Lily, "We're going to make you ... into a proper woman" (Logan 2016: Penny Dreadful 3.7, original pause). Implicitly, the scene invites viewers to revel with the male characters in the imminent vanquishing of the female monster - arguably standing for the 'monster' of activist feminism in a postfeminist age.

More than mere adherence to Gothic genre conventions of persecuted heroines, this constitutes a strategic presentist choice. Not least, the pathologization of women as madwomen (which also applies to Vanessa Ives) has been extensively deconstructed by feminist critics as a targeted form of political disempowerment and silencing of women's dissent, most famously by Sandra M. Gilbert and Susan Gubar in The Madwoman in the Attic: The Woman Writer and the Nineteenth-Century Literary Imagination (1979) and Elaine Showalter in The Female Malady: Women, Madness, and English Culture, 1830-1980 (1985). Indeed, this critical discourse is directly alluded to in Lily's debate with the "deluded" Victor about what she terms his intention to turn her into "a non-person": "Even if you keep me in the attic, render me with the mind of an obliging child, I will always see that dark little space that so yearns to be a soul" (Logan 2016: Penny Dreadful 3.8). Yet crucially, Lily's feminism fails to persuade her captor; Victor only frees her once she adopts the more 
culturally acceptable role of the suffering mother. Confessing her guilt for the demise of her infant daughter (who died of cold as her mother prostituted herself to procure food), Lily begs Victor not to "take" her daughter from her all over again (Logan 2016: Penny Dreadful 3.8), by erasing the painful memories and psychological scars that have driven her to her monstrous actions. Her brief return to Dorian's mansion and the discovery of Justine's corpse replays the failed mother's guilt: "So my great enterprise comes to no more than this. One more dead child" (Logan 2016: Penny Dreadful 3.9). Here too Lily's disavowal of her inappropriate "great enterprise" implicitly equates feminism with madness. Too often, then, Penny Dreadful recycles pejorative gender stereotypes as a sort of unquestioned default position, reiterating rather than contesting the presumed necessity of male control over unruly women, who must once again be saved from themselves rather than from abusive men. So too in the case of Vanessa Ives, who having become Dracula's willing bride embracing her own darkness, begs and receives the deliverance of death from the hands of her former lover, Ethan Chandler, at the series finale.

Although Penny Dreadful cannot be taken as representative of the neo-Victorian phenomenon as a whole, it exemplifies the lures of critical presentism and its vexing operations and effects - sometimes strikingly at odds with the ethical tendencies commonly associated with neo-Victorianism's defining self-consciousness. Logan's series highlights the need for a much more nuanced analysis of competing modes of neo-Victorian presentism, including antithetical and invidious critical presentism, and these modes' variable interactions with liberal politics, market forces, genre conventions, reader/viewer responses and artists' ideological agendas. More widely, neo-Victorianism's conflicted approach to presentism may reflect the diminishing cultural potency of self-reflexivity in the wane of postmodernism.

The market imperative to sustain the public's desire for ever more Victoriana results in some dubious choices how best to reproduce the past to secure the widest possible consumer base. Viktorija Krombholc observes that neo-Victorianism "has been interpreted both as an example of postmodern subversion of master narratives and a neo-conservative return to those narratives" (Kromnholc 2013: 121). As illustrated by Penny Dreadful's increasingly strained 'feminism', even one-and-the-same text may fall into both categories or employ (simulated?) subversion to pursue reactionary tendencies. Neo-Victorian presentism can thus end up obscuring rather than foregrounding its strategic manipulations of both past and present contexts, rendering readers/viewers less rather than more sensitive to the cognitive maps through which we mediate and interpret - and misrepresent and distort diegetic as well as extradiegetic history. At its best, neo-Victorian critical presentism resists the temptation to make worlds and texts fit pre-defined patterns or plots. At its worst, invidious critical presentism substitutes the same old stories for neo-Victorian readings of difference and reading differently.

\section{Notes}

1. 'Neo-Victorian' functions as an umbrella term, referring to contemporary works set in or otherwise engaging extensively with the nineteenth century and its sociocultural legacies, hence also encompassing texts with modern settings. Debate continues about the appropriate parameters of the 'neo-Victorian' appellation. While mainly applied to works centred in British and British colonial contexts, it is also employed in wider global and postcolonial contexts, for instance neo-slavery narratives set in the USA or detective fiction set in the declining Ottoman Empire. Besides adaptations, the most prominent neo-Victorian modes include biofiction (about real-life persons); the Gothic; neo-sensation, crime and detective fiction; conflict and trauma narratives (for instance about the Indian Mutiny or the Irish 
Famine); and "sexsation" fiction (Kohlke 2008: 53 and passim) focused on sexual awakenings and/or sexploitation. Frequently various modes overlap.

1. This tendency is most explicit in narratives, such as A.S. Byatt's Possession: A Romance (1990), which employ parallel nineteenth-century and present-day time-frames, often involving postmodern characters' archival investigations into the past, or in texts that feature metafictionally intrusive, twentieth-/twenty-first-century narrators who comment on the historical period portrayed, as in John Fowles' The French Lieutenant's Woman (1969) and Michel Faber's The Crimson Petal and the White (2002).

1. Barrish applies the terms to an "almost entirely middle class" (Barrish 2001: 4) strand of American literary realism from 1880-1995 which sought to establish its "intellectual prestige" (1) by claiming to convey truer insights than scientific, empirical and statistical studies could provide into radically disparate lives, including those of the working classes, immigrants, and abject poor. A comparable imaginative projection - along temporal rather than class lines - is discernible in neo-Victorianism, even when writers opt for non-realist modes such as the Gothic.

1. This strand includes Mudrooroo Nyoongah's (Colin Johnson's) Doctor Wooreddy's Prescription for Enduring the Ending of the World (1983), Robert Edric's Elysium (1995), Matthew Kneale's English Passengers (2000), Kate Grenville's The Secret River (2005), and Richard Flanagan's Wanting (2008). For an insightful treatment of the topic, see Mitchell (2010b).

1. 'Edutainment', a conflation of 'education' and 'entertainment', relates to the commonplace assumption that nowadays the majority of the general public gains its knowledge of history from popular media (TV, films, fiction, videogames, etc.) rather than from history books and documentaries.

1. The 1918 Act only allowed "women over the age of 30 who met a property qualification to vote", restricting suffrage to a mere forty percent of all British women (Parliament UK 2016: n.p.). It took another decade and the Equal Franchise Act 1928 for voting rights to be extended to all women over 21.

1. These include Jessica Hynes's television suffragette comedy Up the Women (BBC Four, 2013), Amanda Vickery's documentary Suffragettes Forever! The Story of Women and Power (BBC Two, 2015), and the much-hyped film Suffragette (2015), directed by Sarah Gavron and written by Abi Morgan; also see Jessica Swale's play Blue Stockings (2013) about women's fight for full access to higher education.

1. For a perceptive discussion of the inherent contradictions in Adler's characterisation and her sometimes unexpectedly anti-feminist deployment, see Primorac (2013). Interesting parallels may be drawn between Adler and Penny Dreadful's female anti-heroines and villains in this sense.

1. MacDonald and Goggin borrow the term from Cora Kaplan's Victoriana (2007). Kaplan uses it to describe the typically sexually transgressive woman in neo-Victorian fiction who strives for self-definition and has a palimpsestic literary genealogy stretching from Daniel Defoe's Moll Flanders (1722) to Thomas Hardy's “maddened heroines" (Kaplan 2007: 109).

1. Early in the inaugural episode, the script "London, September 22, 1891" is superimposed over the scene of a Wild West Show, attended by Vanessa (Logan 2016: Penny Dreadful, 1.1); however, the exact passage of time across individual seasons or the series as a whole remains unclear.

1. When her mentor pronounces that "[a]11 men are utter slaves to their desires" and thus legitimate targets for retribution, Justine queries whether this includes Dorian and dismisses Lily's defence that Dorian is "an exceptional creature" with the pointed statement, "He's a man" (Logan 2016: Penny Dreadful 3.3). Later, when Dorian insists to Lily that "My place is 
at your side. We are equals, partners", she points out that, as a man, he "cannot know" or ever fully share the women's suffering (Logan 2016: Penny Dreadful 3.6).

1. MacDonald and Goggin pertinently note the relative "absence of functioning feminist communities [...] in many neo-Victorian media", with works "more often interested in showcasing the ills of Victorian society - and implicitly our own - rather than demonstrating the gains made by feminists in the Victorian period" (MacDonald and Goggin 2013: 7). As much is illustrated by Lily's prostitute 'collective'.

\section{Works Cited}

Alcorn, Marshall W. Jr. and Mark Bracher. 1985. 'Literature, Psychoanalysis, and the ReFormation of the Self: A New Direction for Reader-Response Theory'. PMLA 100.3 (May): 342-354. JSTOR.

Barrish, Phillip. 2001. American Literary Realism, Critical Theory, and Intellectual Prestige, 1880-1995. Cambridge Studies in American Literature and Culture. Cambridge: Cambridge UP. ProQuest ebrary.

- 2005. White Liberal Identity, Literary Pedagogy, and Classic American Realism. Columbus, OH: The

Barry, Peter. 2008. 'Developments in Literary Theory since 1995'. Modern British and Irish Criticism and Theory: A Critical Guide. Ed. Julian Wolfreys. Edinburgh: Edinburgh UP: 190-197. ProQuest ebrary.

Boehm-Schnitker, Nadine, and Susanne Gruss. 2014. 'Introduction: Fashioning the NeoVictorian-Neo-Victorian Fashions'. Neo-Victorian Literature and Culture: Immersions and Revisitations. Eds. Nadine Boehm-Schnitker and Susanne Gruss. New York and London: Routledge: 1-17.

Burstein, Miriam. 2006. 'Rules for Writing Neo-Victorian Novels'. The Little Professor: Things Victorian and academic. 15 March.

http://littleprofessor.typepad.com/the_little_professor/2006/03/rules_for_writi.html (accessed 30 May 2012). Online/Open Access.

Connor, Steven. 1996. The English Novel in History 1950-1995. London and New York: Routledge. ProQuest ebrary.

Davies, Helen. 2015. Neo-Victorian Freakery: The Cultural Afterlife of the Victorian Freak Show. Houndmills, Basingstoke and New York: Palgrave Macmillan. Print.

Gajowski, Evelyn. 2010. 'Beyond Historicism: Presentism, Subjectivity, Politics'. Literature Compass 7.8 (August): 674-691. Wiley Online Library Full Collection.

Grady, Hugh. 2007. 'Why Presentism Now?'. SHAKSPER Roundtable: Presentism: n.p. http://shaksper.net/archive/2007/248-january/25262-shaksper-roundtable-presentism (accessed 7 September 2016). Online/Open Access.

Grady, Hugh and Terence Hawkes. 2007. 'Introduction: Presenting presentism'. Presentist Shakespeares. Eds. Hugh Grady and Terence Hawkes. London and New York: Routledge: 1-5. Print.

Gutleben, Christian. 2001. Nostalgic Postmodernism: The Victorian Tradition and the Contemporary British Novel. Amsterdam and New York: Rodopi. Print.

Hadley, Louisa. 2010. Neo-Victorian Fiction and Historical Narrative: The Victorians and Us. Houndmills, Basingstoke and New York: Palgrave Macmillan. Print.

Heilmann, Ann and Mark Llewellyn. 2010. Neo-Victorianism: The Victorians in the TwentyFirst Century, 1999-2009. Houndmills, Basingstoke and New York: Palgrave Macmillan. Print. 
Ho Lai-Ming, Tammy. 2012. 'Cannibalised Girlhood in Richard Flanagan's Wanting'. NeoVictorian Studies 5.1, Special Issue: The Child in Neo-Victorian Arts and Discourse: Renegotiating 19th Century Concepts of Childhood, 14-37. Online/Open Access.

Holbo, John. 2008. 'Shakespeare Now: The Function of Presentism at the Critical Time'. Literature Compass 5:6 (November): 1097-1110. Wiley Online Library Full Collection.

Holland, Norman. 1975. 'Unity Identity Text Self'. PMLA 90: 813-822. Print.

Hutcheon, Linda. 1988. 'Historiographic Metafiction: "the pastime of past time"'. A Poetics of Postmodernism: History, Theory, Fiction. New York and London: Routledge: 105-123. Print.

Kaplan, Cora. 2007. Victoriana: Histories, Fictions, Criticism. Edinburgh: Edinburgh UP. Print.

Kohlke, Marie-Luise. 2008. 'Sexsation and the Neo-Victorian Novel: Orientalising the Nineteenth Century in Contemporary Fiction'. Negotiating Sexual Idioms: Image, Text, Performance. Eds. Marie-Luise Kohlke and Luisa Orza. Amsterdam and New York: Rodopi: 53-77. Print.

- 2013. 'Neo-Victorian Biofiction and the Special/Spectral Case of Barbara Chase-Riboud's Hottentot

Krombholc, Viktorija. 2013. 'Objects in Mirror Are Closer Than They Appear: On the Nature of Fictional Returns to the Nineteenth Century'. Kultura 138: 117-129. Online/Open Access.

Krueger, Christine L. 2002. 'Introduction'. Functions of Victorian Culture at the Present Time. Ed. Christine Krueger Athens, Ohio: Ohio UP: xi-xx. Print.

Logan, John (Creator and Writer). 2014. Penny Dreadful, Season One. Executive Prod. Sam Mendez and John Logan. Showtime/Sky: May 11, 2014-June 29, 2014. Paramount Home Entertainment. DVD.

—. 2016. Penny Dreadful, Season Three. Executive Prod. Sam Mendez and John Logan. Showtime/Sky:

MacDonald, Tara and Joyce Goggin. 2013. 'Introduction: Neo-Victorianism and Feminism'. Neo-Victorian Studies 6.2, Special Issue: Neo-Victorianism and Feminism: New Approaches: 1-14. Online/Open Access.

Mitchell, Kate. 2010a. History and Cultural Memory in Neo-Victorian Fiction: Victorian Afterimages. Houndmills, Basingstoke and New York: Palgrave Macmillan. Print.

—. 2010b. 'Australia's "Other" History Wars: Trauma and the Work of Cultural Memory in Kate Grenvi Rodopi: 253-282. Print.

Parliament UK. 2016. 'Living Heritage: Women and the Vote', http://www.parliament.uk/about/living-

heritage/transformingsociety/electionsvoting/womenvote/overview/thevote/ (accessed 16 August 2016). Online/Open Access.

Primorac, Antonija. 2013. 'The Naked Truth: The Postfeminist Afterlives of Irene Adler'. Neo-Victorian Studies 6.2, Special Issue: Neo-Victorianism and Feminism: New Approaches: 89-113. Online/Open Access.

Poore, Benjamin . 2016. 'The Transformed Beast: Penny Dreadful, Adaptation, and the Gothic'. Victoriographies - A Journal of Nineteenth-Century Writing, 1790-1914 6.1: 62-81. Online/www.euppublishing.com.

Seidman, Steven. 1985. 'The Historicist Controversy: A Critical Review with a Defense of a Revised Presentism'. Sociological Theory 3.1 (Spring): 13-16. JSTOR.

Take Back the Night. N.d. 'About Take Back the Night ${ }^{\circledR}$ '. http://takebackthenight.org/about-tbtn/ (accessed 15 June 2016). Online/Open Access. 